\title{
Productivity Swings and Housing Prices
}

\author{
James A. Kahn
}

\begin{abstract}
The housing boom and bust of the last decade, often attributed to "bubbles" and credit market irregularities, may owe much to shifts in economic fundamentals. A resurgence in productivity that began in the mid-1990s contributed to a sense of optimism about future income that likely encouraged many consumers to pay high prices for housing. The optimism continued until 2007, when accumulating evidence of a slowdown in productivity helped dash expectations of further income growth and stifle the boom in residential real estate.
\end{abstract}

A widely held view among market observers is that the rapid growth in home prices from the mid-1990s until the recent crash reflected a "bubble," brought on by excessively lax lending standards and a belief that house prices would increase indefinitely. ${ }^{1}$ In this view, the bubble was destined to burst, triggering a dramatic decline in the housing sector.

This edition of Current Issues offers a different perspective on the source of the housing boom and bust of the last decade. We argue that changing economic fundamentals - specifically, swings in labor productivity, or output per hour of workplayed a significant role in the movements of housing prices. ${ }^{2}$ These productivity swings helped determine the price of housing through their effects on income growth and long-term income expectations-factors that directly influence what consumers are ready to pay for housing and what mortgage providers are willing to lend.

Using a recently developed model of housing prices, we show how a large share of price fluctuations over the last forty-five years can be attributed to changes in productivity growth. Applied to the most recent housing cycle, the model suggests that the surge in home prices from the mid-1990s to 2007 was fueled at least in part by the belief that ongoing productivity advances would lead to continued strong growth in income. The relationship worked in reverse as evidence mounted in 2007 that productivity growth had slowed: At that time, expectations of further income growth declined, helping to quash the housing boom and jeopardizing mortgages and other investments predicated on continued expansion.

This argument attaches considerable importance to the perception of productivity shifts. Housing market participants were slow to perceive the most recent decline in the rate of productivity growth because the data released through mid-2007 gave little indication of it. Subsequent revisions of the data made it clear that productivity had in fact begun to decelerate in 2004. Nevertheless, given the information available through much of the current decade, borrowers and lenders might reasonably have inferred that productivity growth remained strong — an inference that would encourage optimism about income prospects and hence higher expenditures on housing.

\footnotetext{
1 See, for example, Baker (2006).

2 During the housing boom, McCarthy and Peach (2005) put forward a similar argument, although it was based on different methods. Himmelberg, Mayer, and Sinai (2005) contend that in most local markets, prices did not appear to be misaligned with economic fundamentals.
} 
Chart 1

\section{Trends in U.S. Inflation-Adjusted Home Price Indexes}

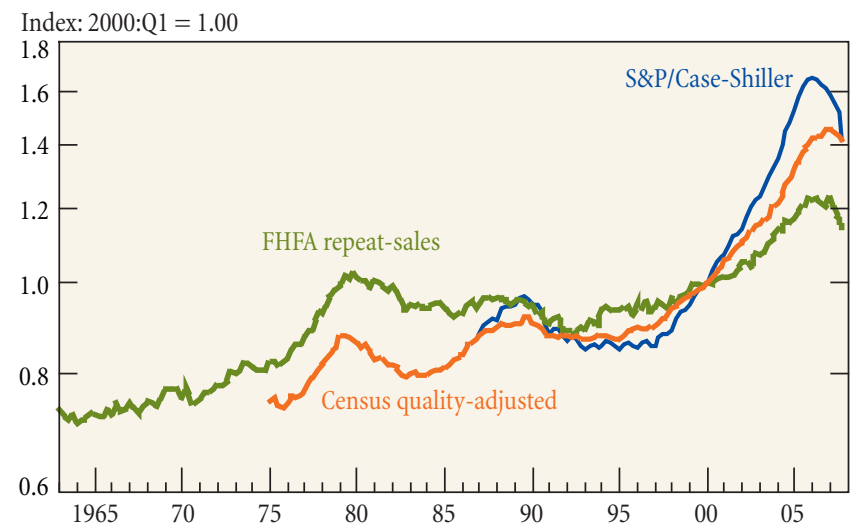

Sources: Federal Housing Finance Agency (FHFA); U.S. Bureau of the Census; Standard and Poor's (S\&P).

Note: The vertical axis is a logarithmic scale.

Of course, we do not discount the view that other factors, such as changes in interest rates and credit market conditions, contributed to the surge and decline in home prices. Our contention is simply that an exclusive focus on these factors obscures the arguably equally important influence of productivity swings on housing and thus exaggerates the role of credit markets.

\section{Parallel Trends in House Prices and Productivity}

Since the early 1960s, movements in inflation-adjusted house prices have broadly resembled sustained movements in labor productivity relative to its long-term trend. A look at aggregate U.S. home price indexes ${ }^{3}$ over the last half-century reveals three major trends in inflation-adjusted home prices: rising prices through the 1970s, a flat or declining period between 1979 and the mid-1990s, and a decade of strong growth through 2007 (Chart 1). ${ }^{4}$

These broad patterns correspond roughly with movements in productivity around its historical average trend (Chart 2). The upswing in house prices in the 1960s and 1970s took place when productivity was believed to be trending up at an annual rate of nearly 3 percent. A period of real price declines that began in the late 1970s coincided with the recognition of a productivity growth slowdown to a sustained rate of less than 1.5 percent. The second boom in housing prices, which started in the late 1990s,

\footnotetext{
${ }^{3}$ We deflate the indexes by an aggregate price index known as the personal consumption expenditures deflator to eliminate swings in home values in response to overall price inflation. For instance, home prices rose in actual dollars more rapidly in much of the high-inflation 1970s than in the past decade-but the economics underlying the current-dollar price run-ups in the two periods were quite different.

4 The differences between the indexes reflect both conceptual differences and indexation bias. For example, because new homes tend to be built on less expensive land, their prices are typically less sensitive to land values than are the prices of existing homes.
}

Chart 2

\section{Trends in Productivity}

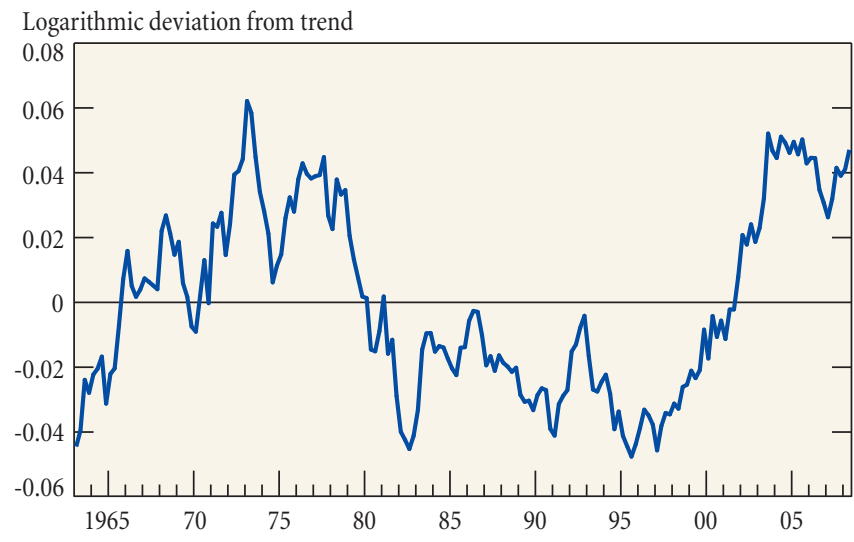

Sources: U.S. Bureau of Labor Statistics; author's calculations.

Note: Productivity is measured as nonfarm output per hour relative to a linear (constant-growth) trend.

occurred around the time many analysts determined that productivity had rebounded to its earlier high-growth rate. Finally, the latest downturn in housing prices and housing sector activity coincides with signs of a deceleration in productivity.

While the observed association of prices and productivity movements is suggestive, it does not necessarily imply an economic connection between the two. In the next section, we explain why productivity trends influence housing prices.

\section{Economic Fundamentals and Housing Prices}

During the most recent housing boom, the Census' constantquality index of new home prices, adjusted for inflation, rose approximately 33 percent. In the bust following the first-quarter 2007 peak, that same measure has fallen by nearly 15 percent. $^{5}$ The sharp swings in house prices raise a question: Are these movements driven by economic fundamentals, or by irrational behavior that can trigger bubbles and busts? One indication of a bubble is that "the level of prices has been bid up beyond what is consistent with underlying fundamentals" (McCarthy and Peach 2005). This observation suggests that a logical way to explore the forces behind the recent housing price movements is to establish the magnitude and timing of the price shifts that would be warranted by changes in fundamentals alone.

Calculations of this kind require the use of an economic model. In this article, we employ a model that emphasizes one fundamental, trend productivity growth, as a key driver of

\footnotetext{
5 The increase occurred from the fourth quarter of 1995 to the first quarter of 2007. Prices of existing homes rose considerably more during a similar period-66 percent according to the FHFA index and more than 90 percent by the S\&P/Case-Shiller series — and have subsequently fallen sharply from their peaks ( 9 percent for the FHFA index and nearly 30 percent for the S\&P/Case-Shiller index).
} 
housing price trends. ${ }^{6}$ Productivity growth is especially well suited for a model of aggregate house prices. Many of the other fundamentals that affect housing prices-demographic factors, density (the availability of land per capita), interest rates, taxes, and local government regulations affecting new construction (see Glaeser, Gyourko, and Saks [2005]) — can vary widely across regions; they may result in local booms or busts (see Himmelberg, Mayer, and Sinai [2005]) but will average out or dissipate in the aggregate. Productivity growth, by contrast, varies substantially over time in the economy as a whole. It exhibits precisely the kinds of unexpected but long-lasting changes that have the potential to influence the forward-looking price of an asset like housing.

How does productivity growth influence house prices? Economists generally regard productivity growth as the single most important determinant of long-run trends in household income. Thus, stronger productivity growth will lead to both faster income growth and higher expectations for future income. In turn, a sustained rise in income will significantly strengthen the current and future demand for housing. Finally, the increase in demand will drive up the price of land and hence "the rental price of housing," - that is, the market price of the services (space and shelter) that owners derive from living in their homes.

A house is an asset, so its price should reflect the value, discounted to the present, of the services that the house provides over its lifetime. Thus, the price of a house will depend not only on current income, but also on expectations of future income growth, because together they drive the present and future demand for housing services.

\section{A Model of Housing Prices}

Drawing on the relationships between productivity, income, and demand, the model quantifies the impact of changes in productivity trends on the magnitude and timing of house price movements over the 1963-2008 period. To this end, the analysis incorporates "real-time" assessments of productivity trends over the past fortyfive years. These assessments, computed using a methodology presented in Kahn and Rich $(2006,2007)$, draw on vintage data sets to detect shifts between "regimes" of high productivity growth and low productivity growth from the viewpoint of housing market participants at various points in the past. In other words, these calculations tell us when market participants, responding to the information available at the time, were able to recognize that a sustained slowdown or acceleration of productivity growth was under way. Such a recognition would be necessary before changes in productivity could be expected to alter income expectations or to prompt a reversal in the growth pattern of housing prices. Thus, by including the real-time assessments in the model, we are better able to explain the timing of the house price movements in recent decades. Indeed, as we shall see, the turning points in housing prices correlate well with the shifts in productivity trends as they were discerned in real time.

\footnotetext{
${ }^{6}$ The model is described in greater detail in Kahn (2008a).
}

\section{The Elasticity of Demand}

A product's demand elasticity is considered low (less than 1) if, in response to a price increase, total spending - price times quantityon the product increases; it is considered high (greater than 1) if total spending decreases. The intermediate case (elasticity of 1) exists when spending on a product does not vary in response to a price change-in other words, the reduced quantity just offsets the price increase.

To determine elasticity as accurately as possible, we can look across different locations and time periods for variation in the cost of housing services to ascertain the extent to which expenditures on housing services rise or fall with changes in their cost. The more elastic the demand, the smaller the increase in housing expenditures for a given price increase. Specifically, in response to an $x$ percent price increase, expenditures rise by $x(1-\varepsilon)$ percent, where $\varepsilon$ is demand elasticity. For example, suppose over a ten-year period the price of housing services increased 10 percent in one region, relative to the prices of other goods, while relative expenditures on housing rose 6 percent. This would imply an elasticity of 0.4 .

In a regional analysis, Kahn (2008a) arrives at elasticity estimates of 0.2 to 0.3 using the Bureau of Labor Statistics' Consumer Expenditure Survey data; Flavin and Nakagawa (2008) produce an even smaller estimate of 0.13 using data from the University of Michigan's Panel Study of Income Dynamics. The findings are consistent with earlier results on the relatively inelastic demand for housing.

Our model predicts a path for house prices over 1963-2008 that is based on the productivity data and on estimates of the relationship between income, house prices, and demand. When productivity growth accelerates, the amount by which house prices will rise depends on certain basic supply and demand relationships. The fact that land, a finite resource, is a relatively large component of housing (compared with its "share" in other goods) makes the overall supply of housing relatively unresponsive to demand changes; the supply of houses cannot expand indefinitely to meet increases in demand. In addition, because housing is viewed as a necessity that has no obvious substitute among other kinds of goods, consumers faced with a rise in housing prices will be relatively unwilling to curtail their demand for housing. Thus, the demand for housing services is relatively inelastic - that is, insensitive to price changes. Indeed, our model incorporates a very low demand elasticity of 0.3 , based on the calculations described in the box above. This combination of price-inelastic demand and supply means that productivity swings affecting the demand for housing can result in large changes in house prices. ${ }^{7}$

How large? According to our model, the insensitivity of housing demand to price changes implies that in times of aboveaverage economic growth, house prices can grow faster than income (and faster than rents) for periods of many years, even decades. In an expanding economy, an inelastic demand for

\footnotetext{
7 The model assumes an income elasticity of one-meaning that the demand for housing services, holding prices fixed, rises one-for-one with increases in income.
} 
housing services requires the price of land, and therefore the price of housing, to rise to a level above its long-run trend - with more new homes being built—before supply and demand equalize. The opposite is true if the economy slows: If demand for housing is very insensitive to price, the price of land and housing will need to fall to a level below trend. In essence, price-inelastic demand results in a "multiplier effect," in which home prices grow faster than income during housing booms and decline faster than income during contractions. This is precisely what happened during the recent housing boom and bust in the United States and in similar episodes that occurred earlier in time or in other countries. ${ }^{8}$ While such price swings are often cited as an indication of a "bubble," we argue that they can arise naturally from productivity shifts affecting the demand for housing.

\section{The Recognition of Shifts in Productivity Growth}

We argued earlier that the timing and magnitude of house price movements will depend on housing market participants' recognition of changing productivity trends. Significantly, this recognition can lag the actual trend shift by a number of years. To shed light on market participants' perception of productivity changes, we draw on the Kahn-Rich $(2006,2007)$ methodology described earlier, which detects shifts in the mean growth of rate of labor productivity between regimes of high and low growth.

We first identify these shifts "retrospectively," using all data currently available in order to capture the magnitude and timing of the shifts with the accuracy that hindsight allows. The retrospective assessments in the 2006-07 studies by Kahn and Rich, for example, revealed a shift from high mean growth to low mean growth in 1973, and a move back to high mean growth in 1997. In this analysis, using data through 2008 — which include, significantly, data revisions back to 2004 that were released in August 2007-we find that another switch from high to low mean growth likely occurred in mid-2004 (Chart 3).

Next, we use the Kahn-Rich methodology to determine when housing market participants were likely to recognize that these regime shifts had taken place. For this step, we employ, when possible, "vintage" data sets that capture the information that would have been available to market participants at the time. This effort to identify the trend shifts in real time- without the benefit of hindsight—yields telling results. Applied to the 1970s, the realtime assessment does not detect a productivity slowdown until 1979 , some six years after we now know the slowdown occurred. ${ }^{9}$ This recognition lag stems primarily from the unprecedented nature of the slowdown; after twenty-five years of high productiv-

\footnotetext{
${ }^{8}$ See Kahn (2008b).

${ }^{9}$ Edge, Laubach, and Williams (2007) cite other documentary evidence of this lag. Moreover, 1979 was the year in which a number of studies on "the productivity slowdown" first appeared (for example, Denison [1979]). Interestingly, a June 2001 presentation to the Federal Open Market Committee (Steindel 2001) suggests that there were signs of an impending productivity slowdown as early as the late 1960s, but notes "how hard it is to detect in real time that the productivity trend is shifting and by how much."
}

\section{Chart 3 \\ Probability of Being in a High-Productivity-Growth
Regime}

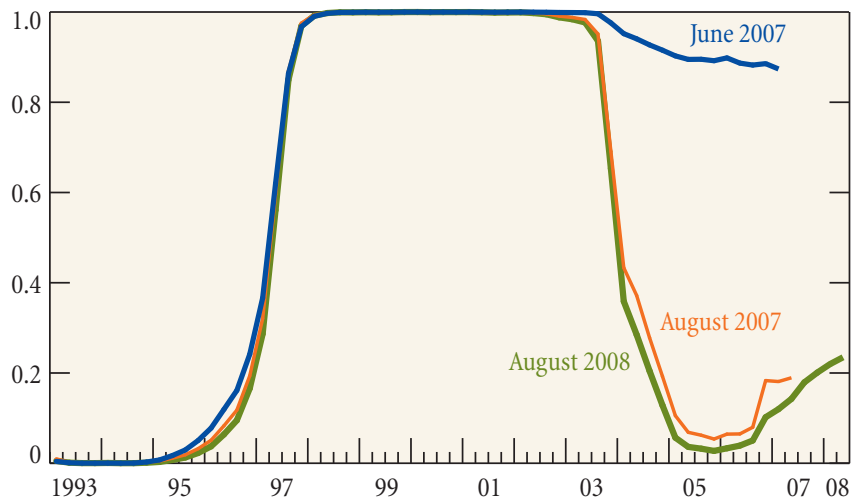

Source: Author's calculations.

Note: Estimates are based on data through the month indicated.

ity growth (the entire period over which data had been collected), market participants would have been likely to interpret signs of slackening productivity as a temporary outcome of the 1973-75 recession rather than the start of a sustained period of lower productivity growth. Applying the same method of identifying real-time productivity changes to the most recent period, we find that market participants would not have recognized the 2004 shift to low productivity growth until 2007. In this case, the delay arose because the data available in 2004-06 suggested continuing high productivity growth - a favorable outlook that would not be overturned until the release of revised data in August 2007.

The delays we have identified support our contention that it is the perception of changes in trend productivity growth that gives rise to movements in housing prices. Both in 1979 and 2007, the recognition of a productivity growth slowdown that had been under way for a few years coincided with the onset of a significant decline in housing prices.

To illustrate how the data available at different points in the past would lead to diverse predictions about future productivity growth, Chart 4 presents five-year-ahead forecasts of productivity growth based on the information available before and after the August 2007 benchmark revisions. As of June 2007, strong productivity growth was expected to continue- a belief that would have provided support for house prices; after the August 2007 release of revised data, the predicted growth rate fell sharply, by roughly 100 basis points. A more recent forecast, based on data released in August 2008, suggests continued slow growth. ${ }^{10}$

We do not contend, of course, that housing market participants actively forecast productivity growth in this manner, or

\footnotetext{
10 This productivity forecast is regularly updated at <http://www.newyorkfed .org/research/national_economy/richkahn_prodmod.pdf $>$.
} 
Chart 4

\section{Real-Time Five-Year-Ahead Forecasts of Productivity Growth}

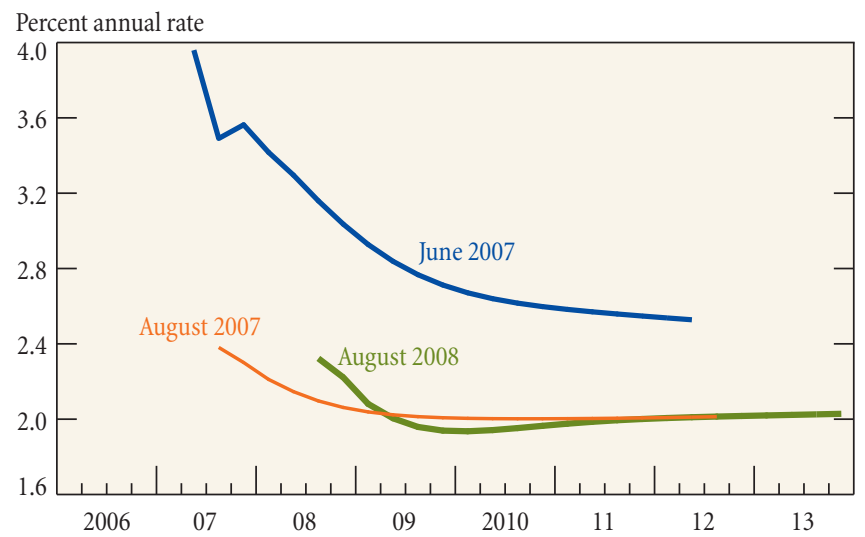

Source: Author's calculations.

Note: Forecasts are based on data through the month indicated.

indeed at all. The forecasts produced by the Kahn-Rich methodology should be seen only as estimates of how participants' expectations evolved over time. Nevertheless, major shifts in housing prices roughly coincided with the shifts in these forecasts. A basic principle of economics is that prices incorporate more information than any one participant possesses. Each individual might only have a sense of his or her own future income prospects when deciding on housing expenditures, but the combined actions of a large number of individuals may result in prices that roughly reflect their collective information.

\section{Productivity and Income}

We have suggested that productivity growth influences housing prices through its effects on income. We recognize, however, that income growth can stem from sources other than longterm changes in productivity - most notably, increases in labor force participation or hours of work per household. While these alternative sources of income growth might be expected to affect household demand and expenditure patterns, they may be less likely than productivity growth to influence housing prices.

First, the additional household income generated from increased labor force participation may be partially offset by additional expenses (see Aguiar and Hirst [2008]). For example, homemakers who enter the labor force may be obliged to pay for child care, transportation, clothing, and food away from home. Such outlays would reduce the impact that higher household earnings stemming from increased labor force participation would have on the demand for housing services.

Second, the changes in workforce participation that result from shifting population demographics such as the aging of the baby-boomers or the increased presence of women in the labor force are relatively predictable. Supply and demand will therefore anticipate these changes, diminishing their impact on house prices.

Third, because labor force participation cannot grow without bound, its effects on income growth will necessarily be finite. There are only so many people who can join the workforce and only so many work hours in the day. Thus, as the increases in labor force participation, particularly among married women, reached their limit in the mid-1990s, household income growth should have begun to slow. The fact that household income instead grew at a rate that was higher than expected (albeit not that much higher in absolute terms) was the direct result of the productivity resurgence after $1995 .^{11}$

The same considerations that lead us to question whether predictable changes in labor force participation could significantly affect the price of housing serve to strengthen the link between productivity shifts and house prices. Productivity growth boosts the income of individual workers without imposing additional expenses on the household. Moreover, trend shifts between regimes of high and low productivity growth occur unexpectedly, and productivity - unlike labor force participation-can increase indefinitely.

\section{Results Derived from the Model}

To implement our model, we incorporate in it the patterns of productivity growth and regime changes over the past forty-five years - and equally important, estimates of housing market participants' real-time assessments of productivity growth - with the aim of determining their implications for housing prices.

Chart 5 presents the results of this exercise for the 1963-2008 period. It plots the house price series generated by the model against the actual path of house prices as represented by the Census quality-adjusted index for new houses. To simulate the model, we base transitory shocks, as well as underlying regime shifts, on estimates produced using the Kahn-Rich methodology. Our results reveal that variation in trend productivity growth accounts for a substantial portion of the timing and magnitude of house price variation. Although the model fails to predict house price movements in the 1960s very accurately (possibly because the large housing stock produced during the postwar homebuilding boom and the unusually small cohort of people born during the Great Depression together kept demand for housing - and therefore the price of housing - lower than expected), it successfully predicts the house price trends in subsequent decades. Note in particular the run-up in prices captured by the model beginning in the 1990s and the sharp downturn beginning in 2007.

\footnotetext{
11 Specifically, inflation-adjusted mean family income grew at a 0.95 percent annual rate from 1973 to 1996 and 1.1 percent rate from 1996 to 2005—only the slightest increase despite the much larger increase in productivity growth. However, much of the growth in the earlier period was attributable to an increase in the number of earners per family. In families with one earner, mean real income grew only 0.3 percent from 1973 to 1996, compared with 1.4 percent from 1996 to 2005 (U.S. Bureau of the Census, Historical Income Tables, Table F-12).
} 
Chart 5

\section{New Home Price Index Compared with House Price Series Generated from the Model}

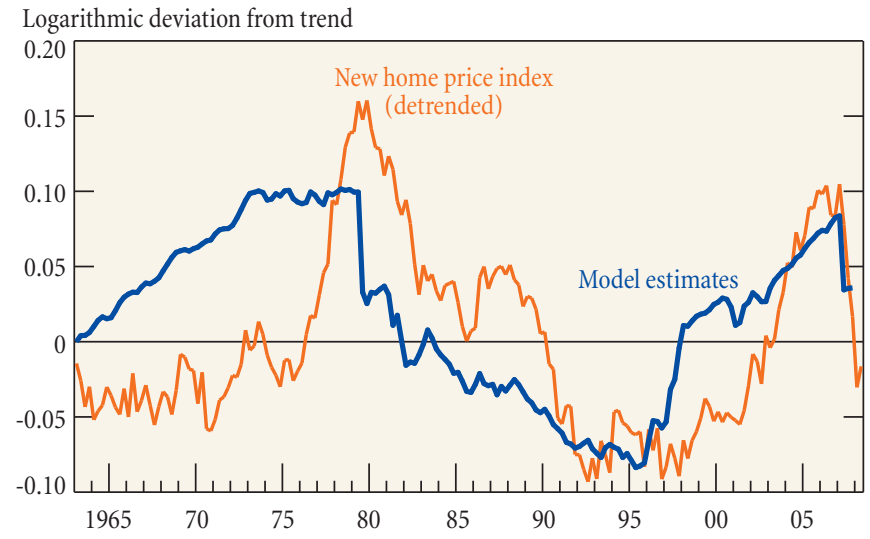

Sources: U.S. Bureau of the Census; author's calculations.

To be sure, the model's price series leads the data in the 1990sperhaps because the real-time data methodology is too effective at detecting trend productivity changes - but overall it captures the boom and subsequent downturn remarkably well. ${ }^{12}$

The close association revealed by the model between turning points in house prices and changes in trend productivity does not preclude the influence of other factors on the housing sector. Chart 5 shows, in addition to the deviation in the 1960s, other notable, though relatively transient, intervals in which the actual path of prices departs from the model's predictions, and thus suggests that other factors may be at play. One such factor is interest rates. Many analysts and policymakers believe that a reduction in real interest rates in the early part of this decade, possibly stemming from a worldwide "saving glut" (Bernanke 2005), contributed to the housing boom in the United States and elsewhere. Our model can be adapted to analyze the impact of changes in interest rates on house prices (see Kahn [2008b]). It suggests that while a reduction in interest rates can have a sizable impact on the level of housing prices-indeed on all asset prices - the effect on asset price appreciation is necessarily transitory. For example, a persistent 1 percent reduction in real interest rates could increase house prices by 3 percent or more, depending on how long the reduction is expected to persist, but it could not lead to sustained growth in house prices. That outcome would require continually declining real interest rates, not just a low level of rates. Therefore, lower interest rates in and of themselves would have had a more short-lived impact on house prices, and thus might have been a contributing factor-but not the primary force-behind the most recent housing boom.

\footnotetext{
12 The model's general tendency to lead the data is illustrated by the fact that the model's predicted price is more highly correlated with actual prices one year ahead than with contemporaneous prices.
}

In addition, we do not rule out some independent effect of other changes in credit conditions, such as those that undoubtedly occurred in the 1970s when high inflation and ceilings on interest rates led to massive withdrawals from the banking system, or the more recent subprime mortgage boom and bust. Our model, however, sharply limits the scope of these effects, because much of the price variation is explained without them.

Indeed, our analysis suggests a sequence of events for the recent housing downturn that differs markedly from that put forward by analysts who see tighter credit conditions as the chief source of the downturn. In our view, the productivity slowdown that started in 2004-or, more accurately, its gradual recognition by 2007— put an end to the boom that began in the mid-1990s, as residential investment plummeted and house prices began to decline. Higher interest rates and the rise in foreclosures may have exacerbated the downturn - and made its impact more visible - but they were not the ultimate cause of the housing bust. Thus, we suggest that changing economic fundamentals brought down the housing market and led to the financial distress - not the other way around.

This view gains further support through examination of the boom-and-bust cycle that occurred in the 1970s and 1980s, arguably driven by similar fundamentals but not subsequently associated with comparable financial turmoil. During that episode, loan-to-value ratios were lower than in the recent period and adjustable-rate mortgages were generally unavailable. As Gorton (2008) argues, these factors, as exemplified by the typical subprime mortgage, played a crucial role in increasing the sensitivity of mortgage assets to home prices in the recent episode. In addition, the extent of real price declines in the late 1970s and early 1980s was masked to some degree by higher inflation, making nominal home price declines - and the associated phenomenon of borrowers owning a house worth less than the principal owed on the mortgage-less common. Yet, despite the absence of credit market factors often judged to be the source of the recent housing market developments, prices in the 1970s and 1980s displayed a boom-and-bust pattern not unlike the pattern of the last decade, as shown in Chart 1. Thus, it seems reasonable to assign primacy to fundamentals and only a supporting role to bubbles and credit market irregularities.

These findings, together with the previous discussion of the relationship between productivity growth, income, and housing prices, suggest the following scenario for the most recent housing cycle: With the resurgence in productivity that began in 1995, market participants began to see stronger income growth - not from working longer hours or having a second household income, but on a per hour basis. As individuals became more aware that this stronger growth was attributable to technological progress and that it might be sustainable, they grew more optimistic about their future income, and this optimism directly influenced their willingness to pay for housing. Such optimism would likely have been shared by lenders, who viewed mortgages as less risky 
insofar as income and house prices were growing more rapidly than before.

A decade later, however, signs emerged that the new period of high productivity growth would not be as long-lived as the postWorld War II episode, which had lasted more than twenty-five years. As buyers and lenders began to recognize this, the same process that caused prices to rise and credit conditions to ease began to work in reverse. The expected income growth did not materialize and new buyers entering the market were less willing to pay high prices; thus, prices of houses purchased in recent years failed to grow as expected. Foreclosures began to increase as early as 2005, and lenders became more cautious.

\section{Conclusion}

This article argues that the current housing crisis stemmed in large measure from a change in economic fundamentals and was only exacerbated by credit market conditions. Indeed, what appear in retrospect to be relatively lax credit conditions in the early part of this decade may have emerged in part because of then-justifiable, although ultimately misplaced, optimism about income growth. The subsequent credit crunch can be traced at least in part to a productivity slowdown that began in 2004 but was likely not recognized until 2007. With the slowdown in productivity came a slowdown in the growth and expected future growth of income, which helped to stifle the housing boom and jeopardize mortgages and other investments predicated on ongoing growth. Thus, the U.S. housing sector served as the proverbial "canary in the mineshaft," providing the earliest indication of a deterioration in underlying economic conditions.

The link between productivity and the housing price downturn has important implications going forward. An understanding of this relationship provides insight into the role played by fundamentals in determining the long-term path of home prices. For example, if productivity growth reverts to the higher rates seen in 1996-2004 and 1947-72, our model suggests that housing prices will bottom out and begin growing again faster than overall inflation. Even if productivity growth remains slow, the model implies that housing price declines will ease; but it also suggests that prices could continue to fall modestly on an inflationadjusted basis, as they did in the 1980s and 1990s. Furthermore, a clear understanding of the primary determinants of house prices may help inform policy decisions affecting the current crisis - for instance, by enabling policymakers to gauge the potential impact of credit market interventions on home prices.

\section{References}

Aguiar, Mark, and Erik Hirst. 2008. "Deconstructing Lifecycle Expenditure." NBER Working Paper no. 13893, March.

Baker, Dean. 2006. "The Menace of an Unchecked Housing Bubble." The Economists' Voice 3, no. 4. Available at <http://www.bepress.com/ev/vol3/iss4/art1/>.

Bernanke, Ben S. 2005. "The Global Saving Glut and the U.S. Current Account Deficit." 2005 Homer Jones Lecture, Federal Reserve Bank of St. Louis, St. Louis, Missouri, April 14.

Denison, Edward. 1979. Accounting for Slower Economic Growth: The United States in the 1970s. Washington, D.C.: Brookings Institution.

Edge, Rochelle, Thomas Laubach, and John C. Williams. 2007. "Learning and Shifts in Long-Run Productivity Growth." Journal of Monetary Economics 54, no. 8 (November): 2421-38.

Flavin, Marjorie, and Shinobu Nakagawa. 2008. "A Model of Housing in the Presence of Adjustment Costs: A Structural Interpretation of Habit Persistence." American Economic Review 98, no. 1 (March): 474-95.

Glaeser, Edward, Joseph Gyourko, and Raven Saks. 2005. "Why Have House Prices Gone Up?" American Economic Review 95, no. 2 (May): 329-33. Papers and Proceedings of the 117th Annual Meeting of the American Economic Association.

Gorton, Gary. 2008. “The Panic of 2007." Remarks delivered at the Federal Reserve Bank of Kansas City's Annual Economic Symposium, Jackson Hole, Wyoming, August 25.

Gyourko, Joseph, Christopher Mayer, and Todd Sinai. 2006. "Superstar Cities." NBER Working Paper no. 12355, July.

Himmelberg, Charles, Christopher Mayer, and Todd Sinai. 2005. "Assessing High House Prices: Bubbles, Fundamentals, and Misperceptions." Journal of Economic Perspectives 19, no. 4 (fall): 67-92.

Kahn, James A. 2008a. "What Drives Housing Prices?” Federal Reserve Bank of New York Staff Reports, no. 345, September.

.2008b. “Understanding the World Housing Boom." Paper prepared for the Reserve Bank of Australia Research Workshop on Monetary Policy in Open Economies, December 15-16. Available at <http://www.rba.gov.au/ PublicationsAndResearch/Workshops/2008/>.

Kahn, James A., and Robert W. Rich. 2006. "Tracking Productivity in Real Time." Federal Reserve Bank of New York Current Issues in Economics and Finance 12, no. 8, November.

.2007. “Tracking the New Economy: Using Growth Theory to Detect Changes in Trend Productivity." Journal of Monetary Economics 54, no. 6 (September): 1670-1701.

McCarthy, Jonathan, and Richard W. Peach. 2005. "Is There a Bubble' in the Housing Market Now?" In Is Your Bubble about to Burst? Indianapolis, Ind.: Networks Financial Institute.

Steindel, Charles. 2001. Presentation to the Federal Open Market Committee of the Board of Governors of the Federal Reserve System, June 26-27. Available at $<$ http://www.federalreserve.gov/monetarypolicy/files/FOMC20010627meeting .pdf $>$.

An appendix providing additional details on the connection between interest rates, house prices, and rents is included in the online version of this article, available at $<$ http://www.newyorkfed.org/research/current_issues/ci15-3.html>.

\section{ABOUT THE AUTHOR}

James A. Kahn is the Henry and Bertha Kressel Professor of Economics at Yeshiva University; he was a vice president in the Macroeconomic and Monetary Studies Function of the Federal Reserve Bank of New York when this article was written.

Current Issues in Economics and Finance is published by the Research and Statistics Group of the Federal Reserve Bank of New York. Linda Goldberg and Charles Steindel are the editors. 
APPENDIX

\section{Housing Price Fundamentals}

Housing rents represent the market price that consumers pay for housing services. From the property owner's perspective, rental income net of expenses is analogous to the dividends earned from holding shares of common stock. Because the owner has the option to sell the property and put the proceeds in an interest-bearing security, he must expect a rate of return, adjusted for risk, comparable to the rate on other investments. If $R_{t}$ denotes rental income net of taxes and expenses in year $t$, it should obey the relationship

$$
R_{t}+E\left\{P_{t+1}\right\}-P_{t}=r_{t} P_{t},
$$

where $P_{t}$ is the price of the property at the beginning of year $t, r_{t}$ is the interest rate available on an alternative asset, and $E\left\{P_{t+1}\right\}$ is the expected price as of year $t+1$. The left side represents the total return (income plus capital gains) expected from owning the property, while the right side is the return on an alternative investment with similar risks.

By itself, this relationship has no economic content other than "the law of one price," or what financial economists refer to as "no arbitrage" —namely, that risk-adjusted returns should be equalized. In particular, while the relationship implies that the rent-price ratio $R_{t} / P_{t}$ should be reduced by expected capital gains - it implies that the rent-price ratio is negatively related to expected appreciation rate $E_{t}\left\{\left(P_{t+1}-P_{t}\right) / P_{t}\right\}$-it does not explain which factors drive those expectations. Identifying the factors is one goal of this article. The relationship can also be rearranged into another familiar form in which the current price equals the present discounted value of expected future net rental income. Thus, a property's price reflects expectations of future interest rates, rents, and expenses. 